\title{
Precipitation Synthesis and Formation Process of Ferroelectric $\mathrm{Pb}\left(\mathrm{Fe}_{2 / 3} \mathrm{~W}_{1 / 3}\right) \mathrm{O}_{3}$
}

\author{
Chung-Hsin LU, Kazuo SHINOZAKI and Nobuyasu MIZUTANI \\ $\left(\begin{array}{l}\text { Department of Inorganic Materials, Faculty of Engineering, Tokyo Institute of Technology, } \\ \text { 2-12-1, O-okayama, Meguro-ku, Tokyo } 152\end{array}\right)$
}

\author{
強誘電体 $\mathrm{Pb}\left(\mathrm{Fe}_{2 / 3} \mathrm{~W}_{1 / 3}\right) \mathrm{O}_{3}$ の沈殿合成と生成過程 \\ 呂宗昕・篠嶂和夫・水谷惟恭 \\ (東京工業大学工学部無機材料工学科, 152 東京都目黒区大岡山 2-12-1)
}

\begin{abstract}
Ferroelectric $\mathrm{Pb}\left(\mathrm{Fe}_{2 / 3} \mathrm{~W}_{1 / 3}\right) \mathrm{O}_{3}$ was synthesized by a new two-stage precipitation process. On heating precipitates, $\mathrm{PbWO}$, pyrochlore phase, and $\mathrm{Pb}\left(\mathrm{Fe}_{2 / 3} \mathrm{~W}_{1 / 3}\right) \mathrm{O}_{3}$ formed as major reactants at $300^{\circ}, 510^{\circ}$, and $700^{\circ} \mathrm{C}$, respectively. A small amount of a liquid phase that accelerated densification was also found at $680^{\circ} \mathrm{C}$. A pure compound of $\mathrm{Pb}\left(\mathrm{Fe}_{2 / 3} \mathrm{~W}_{1 / 3}\right) \mathrm{O}_{3}$ formed at $870^{\circ} \mathrm{C}$. However, it melted incongruently at $930^{\circ} \mathrm{C}$ to form $\mathrm{Pb}_{2} \mathrm{WO}_{5}$ and facet-shaped magnetic $\mathrm{PbFe}_{12} \mathrm{O}_{19}$. The predominant formation mechanism of precipitation-derived $\mathrm{Pb}\left(\mathrm{Fe}_{2 / 3} \mathrm{~W}_{1 / 3}\right) \mathrm{O}_{3}$ is considered to include the formation of pyrochlore phase and its subsequent reaction to form $\mathrm{Pb}\left(\mathrm{Fe}_{2 / 3} \mathrm{~W}_{1 / 3}\right) \mathrm{O}_{3}$. The formation process of $\mathrm{Pb}\left(\mathrm{Fe}_{2 / 3} \mathrm{~W}_{1 / 3}\right) \mathrm{O}_{3}$ in the precipitation method is relatively simple in comparison with the solid-state reaction. This is attributed to the improved homogeneity and reactivity of the starting materials in precipitates.

[Received March 15, 1990; Accepted April 13, 1990]
\end{abstract}

Key-words : Precipitation, Synthesis, Formation process, Ferroelectric, $\mathrm{Pb}\left(\mathrm{Fe}_{2 / 3} \mathrm{~W}_{1 / 3}\right) \mathrm{O}_{3}$, Pyrochlore phase

\section{Introduction}

In recent years, solution synthesis techniques such as precipitation, ${ }^{1,2)}$ hydrothermal reaction, ${ }^{31}$ and sol-gel processing ${ }^{4-6)}$ have been utilized to fabricate fine powders of lead complex perovskite compounds having ferroelectric or piezoelectric properties. These techniques not only reduce handling difficulty in physical mixing and repeated calcination process associated with conventional solid-state reaction, but also enhance homogeneity and purity in synthesized ceramics. Certain intermediate compounds (such as parasite pyrochlore phases) that affect the stoichiometry of resultant products and may produce concomitant changes in dielectric properties can be effectively eliminated using solution synthesis. Since resulting species can be alternated or controlled by synthesis methods, the study of the dependence of formation process on synthesis processing is important.

Low-temperature firing $\mathrm{Pb}\left(\mathrm{Fe}_{2 / 3} \mathrm{~W}_{1 / 3}\right) \mathrm{O}_{3}$ has been known as a promising dielectric material for multilayer capacitors. ${ }^{7), 8)}$ It can be easily prepared from mixed oxides through solid-state reaction $;^{91}$ however, its formation process is relatively complicated. The characteristics of its formation process are described as follows:

(1) Several kinds of intermediate compounds containing lead tungstates and unassigned phases appear at $500^{\circ}-650^{\circ} \mathrm{C} .{ }^{10), 11}$

(2) A liquid phase (designated liquid phase ( I )) forming at $690^{\circ} \mathrm{C}$ induces radical. sample shrinkage and causes the formation of facetlike pyrochlore phase. This appearance of liquid phase (I) is attributed to a reaction of unassigned $X$ phase. ${ }^{11}$

(3) After the formation of liquid phase ( I ), the second liquid phase (designated liquid phase (II )) forming at $860^{\circ} \mathrm{C}$ can exist stably at elevated temperatures. ${ }^{121}$

Since the formation process of $\mathrm{Pb}\left(\mathrm{Fe}_{2 / 3} \mathrm{~W}_{1 / 3}\right) \mathrm{O}_{3}$ in solid-state reaction is complicated and difficult to control, we tried to utilize solution synthesis to simplify its processing routes. A two-stage precipitation process was successfully developed to fabricate pure $\mathrm{Pb}\left(\mathrm{Fe}_{2 / 3} \mathrm{~W}_{1 / 3}\right) \mathrm{O}_{3}$. In addition, the formation process of precipitation-derived $\mathrm{Pb}\left(\mathrm{Fe}_{2 / 3} \mathrm{~W}_{1 / 3}\right) \mathrm{O}_{3}$ was investigated. 


\section{Experimental procedure}

The cation solutions were prepared from reagent grade $\mathrm{Pb}\left(\mathrm{NO}_{3}\right)_{2}, \mathrm{Fe}\left(\mathrm{NO}_{3}\right)_{3} \cdot 9 \mathrm{H}_{2} \mathrm{O}$, and $\left(\mathrm{NH}_{4}\right)_{10} \mathrm{~W}_{12} \mathrm{O}_{41} \cdot 5 \mathrm{H}_{2} \mathrm{O}$. Because the precipitate of $\mathrm{PbWO}_{4}$ is easily formed in a mixed solution containing lead and tungsten ions, a synthesis method named two-stage precipitation process was utilized. The procedure of preparation is outlined in Fig. 1. At the first stage of precipitation, tungsten ion solution was blended with lead ion solution in a ratio of $\mathrm{Pb}: \mathrm{Fe}=3: 1$, and a white $\mathrm{PbWO}_{4}$ precursor precipitated immediately. Then iron ion solution was admixed into the resultant suspension solution. At the second stage of precipitation, ammonia was added to convert all of the residual ions to hydroxide precipitates. The as-precipitated powder was filtered and dried prior to grinding.

Differential thermal analysis (DTA) was performed to detect thermal variations at heating and cooling rates of $5^{\circ} \mathrm{C} / \mathrm{min}$, for both as-precipitated powders and compacts. In addition, samples were air-quenched in DTA at required temperatures to analyze the change in resulting compounds and microstructure. Thermogravimetry (TG) and thermal-mechanical analysis (TMA) were also conducted to observe the weight loss and shrinkage of samples at the same heating rate of $5^{\circ} \mathrm{C} / \mathrm{min}$. X-ray diffraction (XRD) was used to identify the products. Scanning electron microscopy (SEM) was used to observe microstructural changes of samples.

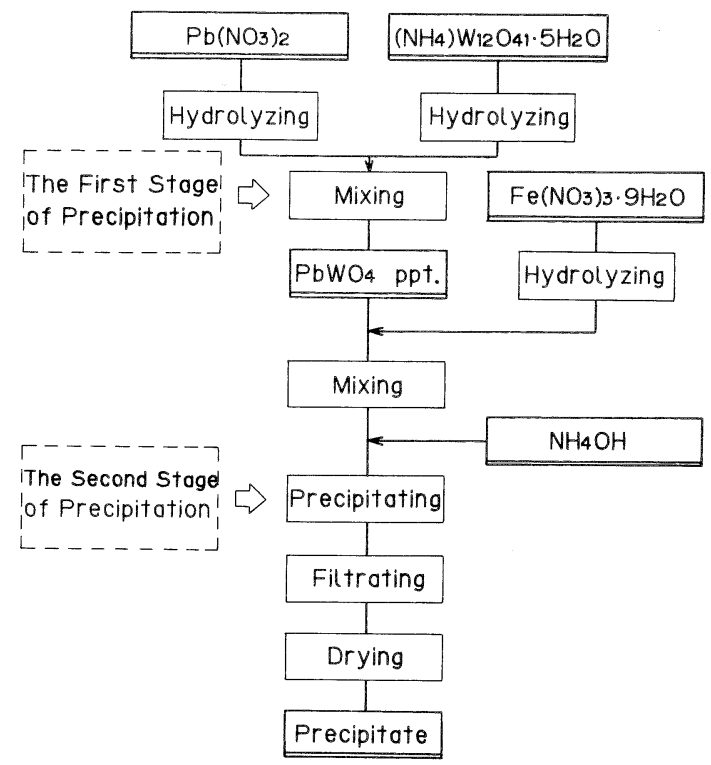

Fig. 1. Flow chart of the two-stage precipitation process for preparing $\mathrm{Pb}\left(\mathrm{Fe}_{2 / 3} \mathrm{~W}_{1 / 3}\right) \mathrm{O}_{3}$.

\section{Results and discussion \\ 3.1 Thermal analysis and $\mathrm{X}$-ray diffraction study}

Figures 2(a), (b), and (c) indicate the TG, DTA, and TMA curves of the as-precipitated $\mathrm{Pb}\left(\mathrm{Fe}_{2 / 3} \mathrm{~W}_{1 / 3}\right) \mathrm{O}_{3}$. At about $400^{\circ} \mathrm{C}$, a total weight loss of $8 \%$ occurred in the TG curve (Fig. 2(a)), and two large endothermic peaks occurred near $100^{\circ}$ and $400^{\circ} \mathrm{C}$ in the heating run $\mathrm{A}$ of DTA (Fig. 2(b)). These endothermic reactions are attributed to be evolution of residual water and ammonia and decomposition of hydroxides in precipitates, which induced the weight loss. In the run $\mathrm{A}$ of $\mathrm{DTA}, 300^{\circ} \mathrm{C}$ exothermic, $680^{\circ} \mathrm{C}$ endothermic, $740^{\circ} \mathrm{C}$ exothermic, and $860^{\circ} \mathrm{C}$ endothermic peaks were also found.

In order to investigate whether the liquid phases existed at $690^{\circ}$ and/or $860^{\circ} \mathrm{C}$ similar to those formed in solid-state reaction, ${ }^{11,12)}$ cooling runs were carried out after $680^{\circ}$ and $860^{\circ} \mathrm{C}$ endothermic peaks as in run $\mathrm{B}$ and $\mathrm{C}$ of Fig. 2(b). As a result, a small exothermic peak appeared at around $665^{\circ} \mathrm{C}$ in run $\mathrm{B}$, whereas no thermal anomaly was observed in run $\mathrm{C}$. The endothermic peak during cooling is considered to be caused by the solidification of liquid phase; ${ }^{111}$ therefore, the liquid phase ( I ) occurring at $680^{\circ} \mathrm{C}$ may exist during reaction, but in small quantity. On the other hand, there was no direct evidence of the presence of the liquid phase (II). On the TMA curve (Fig. 2(c)), a rapid shrinkage of specimens occurred in the range of $650^{\circ}$ to $730^{\circ} \mathrm{C}$. This acceleration of the densification rate is attributed to the existence of liquid phase (I ).

A series of samples were air-quenched in DTA at temperatures higher/lower than DTA peak

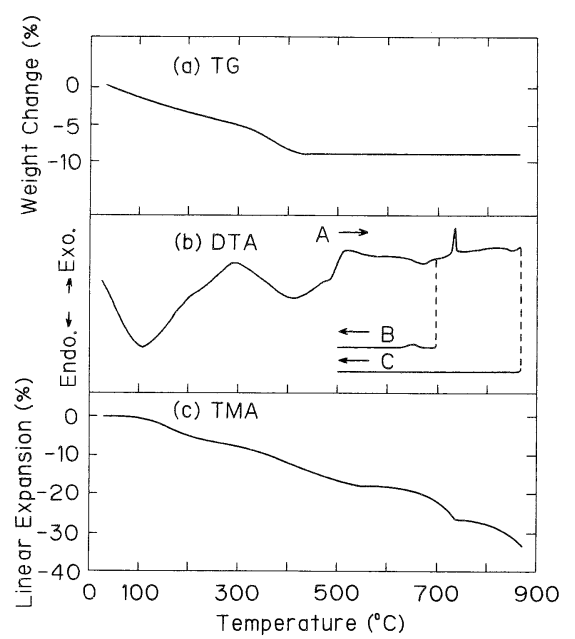

Fig. 2. (a) Thermogravimetry, (b) differential thermal analysis, and (c) thermal-mechanical analysis of precipitation-derived $\mathrm{Pb}\left(\mathrm{Fe}_{2 / 3} \mathrm{~W}_{1 / 3}\right) \mathrm{O}_{3}$. 
temperatures in order to study the variation of resulting products and related reaction sequence. The XRD results are shown in Fig. 3. The as-precipitated powder was completely amorphous. When the samples were heated, three major resulting compounds, i.e. $\mathrm{PbWO}_{4}$, pyrochlore phase, and $\mathrm{Pb}\left(\mathrm{Fe}_{2 / 3} \mathrm{~W}_{1 / 3}\right) \mathrm{O}_{3}$ existed in the formation process. The crystalline form of $\mathrm{PbWO}_{4}$ was formed at about $300^{\circ} \mathrm{C}$. A small quantity of $\mathrm{PbO}$ and $\mathrm{Pb}_{2} \mathrm{WO}_{5}$ were found near $500^{\circ} \mathrm{C}$ and pyrochlore phase formed at a low temperature of $510^{\circ} \mathrm{C}$ and its amount increased up to $700^{\circ} \mathrm{C}$. It is noted that no crystalline forms of

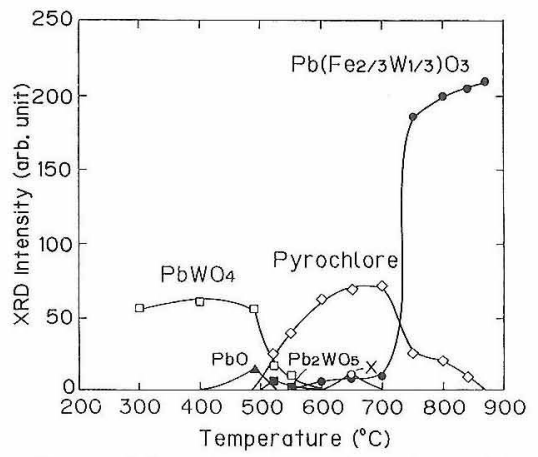

Fig. 3. X-ray diffraction intensity of resulting compounds versus heating temperatures for precipitationderived $\mathrm{Pb}\left(\mathrm{Fe}_{2 / 3} \mathrm{~W}_{1 / 3}\right) \mathrm{O}_{3}$.

$\triangle: \mathrm{PbO}, \square: \mathrm{PbWO}_{4}, \square: \mathrm{Pb}_{2} \mathrm{WO}_{5}, \mathrm{O}: X$ phase, $\diamond:$ Pyrochlore, and $\bigcirc: \mathrm{Pb}\left(\mathrm{Fe}_{2 / 3} \mathrm{~W}_{1 / 3}\right) \mathrm{O}_{3}$
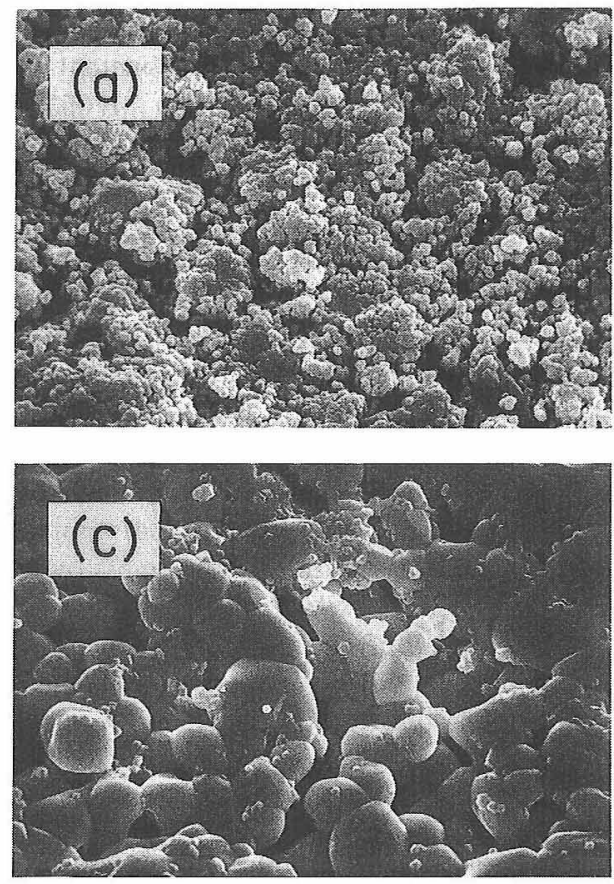

iron compounds could be detected under $500^{\circ} \mathrm{C}$. This is implied that some amorphous compounds containing iron ion coexisted with $\mathrm{PbWO}_{4}$ and $\mathrm{Pb}_{2} \mathrm{WO}_{5}$. After $\mathrm{PbWO}_{4}$ vanished at $600^{\circ} \mathrm{C}$, a small amount of assigned $X$ phase ${ }^{11 \prime}$ occurred at around $650^{\circ} \mathrm{C} . \mathrm{Pb}\left(\mathrm{Fe}_{2 / 3} \mathrm{~W}_{1 / 3}\right) \mathrm{O}_{3}$ began to form at $600^{\circ} \mathrm{C}$ and its formation increased rapidly above $700^{\circ} \mathrm{C}$ accompanied by a corresponding reduction in pyrochlore phase. Heating up to $870^{\circ} \mathrm{C}$, all pyrochlore phase reacted to form pure perovskite $\mathrm{Pb}\left(\mathrm{Fe}_{2 / 3} \mathrm{~W}_{1 / 3}\right) \mathrm{O}_{3}$. Based on the fluorescent $\mathrm{X}$ ray analysis, the composition of the obtained $\mathrm{Pb}\left(\mathrm{Fe}_{2 / 3} \mathrm{~W}_{1 / 3}\right) \mathrm{O}_{3}$ powder nearly consisted with its stoichiometric composition. Together with the results of DTA, the appearance of $740^{\circ} \mathrm{C}$ exothermic peak is attributed to be the formation of $\mathrm{Pb}\left(\mathrm{Fe}_{2 / 3} \mathrm{~W}_{1 / 3}\right) \mathrm{O}_{3}$, and the appearance of the $860^{\circ} \mathrm{C}$ endothermic peak is due to the reaction of pyrochlore phase into $\mathrm{Pb}\left(\mathrm{Fe}_{2 / 3} \mathrm{~W}_{1 / 3}\right) \mathrm{O}_{3}$. Corresponding to the results of mixed oxides, ${ }^{11}$ the unassigned $X$ phase is consideréd to have produced the liquid phase ( I ). In addition, decrease in the amount of $X$ phase resulted in the reduction of liquid phase (I ) in precipitation process.

\subsection{Microstructural observation}

The sequence of microstructural evolution was investigated by SEM. For the samples heated up to $650^{\circ}$ and $700^{\circ} \mathrm{C}$ before and after the formation of the liquid phase (I), the microstructure re-
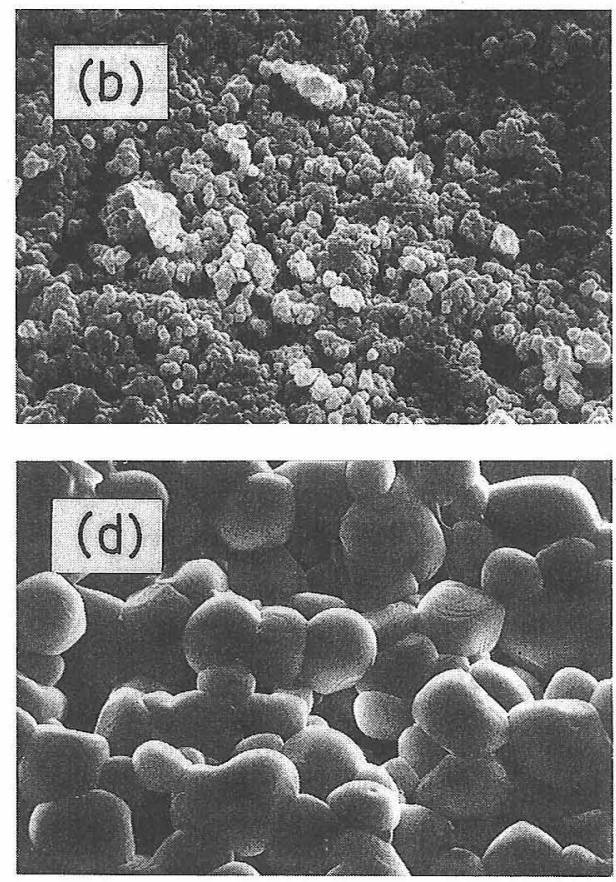

Fig. 4. Scanning electron micrographs of the precipitation-derived $\mathrm{Pb}\left(\mathrm{Fe}_{2 / 3} \mathrm{~W}_{1 / 3}\right) \mathrm{O}_{3}$ at (a) $650^{\circ} \mathrm{C}$, (b) $700^{\circ} \mathrm{C}$, (c) $840^{\circ} \mathrm{C}$, and (d) $870^{\circ} \mathrm{C}$. 
mained apparently unchanged, and the facetlike pyrochlore phase that formed in solid-state reacted samples ${ }^{11)}$ could not be found (Figs. 4(a) and (b)). We can deduce from the above phenomena that decrease in the amount and high homogeneous distribution of the liquid phase ( I ) may reduce the influence on microstructure. The sample quenched at $840^{\circ} \mathrm{C}$ showed the pyrochlore phase of a small particle size dispersed among $\mathrm{Pb}\left(\mathrm{Fe}_{2 / 3} \mathrm{~W}_{1 / 3}\right) \mathrm{O}_{3}$ grains (Fig. $4(\mathrm{c})$ ). The samples quenched at $870^{\circ} \mathrm{C}$ showed only $\mathrm{Pb}\left(\mathrm{Fe}_{2 / 3} \mathrm{~W}_{1 / 3}\right) \mathrm{O}_{3}$ grains (Fig. $4(\mathrm{~d})$ ). $\mathrm{Pb}\left(\mathrm{Fe}_{2 / 3} \mathrm{~W}_{1 / 3}\right) \mathrm{O}_{3}$ began to melt at $910^{\circ} \mathrm{C}$, and all of it incongruently melted and formed $\mathrm{Pb}_{2} \mathrm{WO}_{5}$ and $\mathrm{PbFe}_{12} \mathrm{O}_{19}$ at $930^{\circ} \mathrm{C}$. The decomposed ceramics had magnetic properties due to the presence of $\mathrm{PbFe}_{12} \mathrm{O}_{19}$. The hexagonal-facet idiomorphic shape of $\mathrm{PbFe}_{12} \mathrm{O}_{19}$ was observed and shown in Fig. 5 .

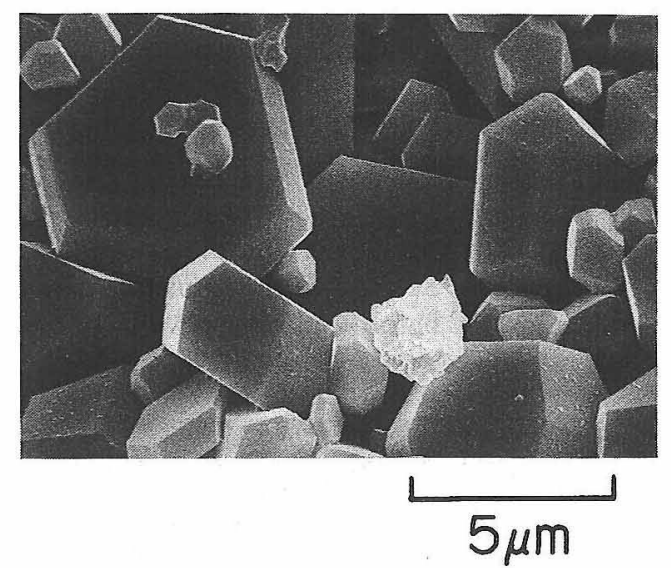

Fig. 5. Scanning electron micrograph of the incongruently melted $\cdot \mathrm{Pb}\left(\mathrm{Fe}_{2 / 3} \mathrm{~W}_{1 / 3}\right) \mathrm{O}_{3}$ at $930^{\circ} \mathrm{C}$.

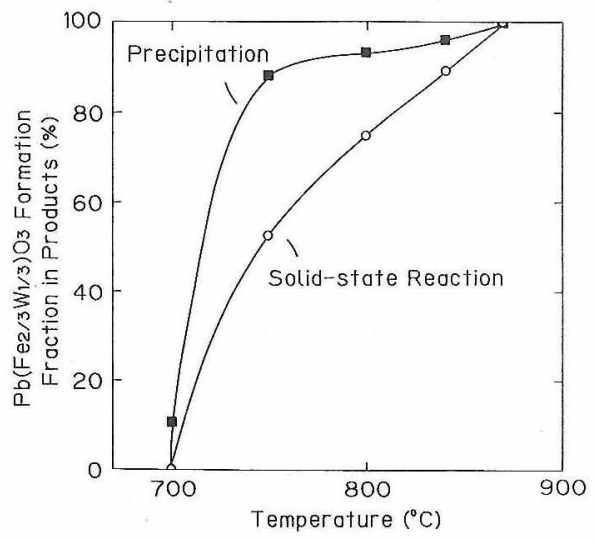

Fig. 6. Formation fraction of $\mathrm{Pb}\left(\mathrm{Fe}_{2 / 3} \mathrm{~W}_{1 / 3}\right) \mathrm{O}_{3}$ in products for precipitation process and solid-state reaction versus heating temperatures (the formation fraction calculated as $I_{0}\left(\mathrm{~Pb}\left(\mathrm{Fe}_{2 / 3} \mathrm{~W}_{1 / 3}\right) \mathrm{O}_{3}\right) /\left(I_{0}\left(\mathrm{~Pb}\left(\mathrm{Fe}_{2 / 3} \mathrm{~W}_{1 / 3}\right) \mathrm{O}_{3}\right)\right.$ $+I_{0}$ (pyrochlore) $)$.

\section{3 Formation process}

The formation fraction of $\mathrm{Pb}\left(\mathrm{Fe}_{2 / 3} \mathrm{~W}_{1 / 3}\right) \mathrm{O}_{3}$ in heated samples was calculated as the ratio of the XRD intensity of $\mathrm{Pb}\left(\mathrm{Fe}_{2 / 3} \mathrm{~W}_{1 / 3}\right) \mathrm{O}_{3}$ to the sum of the XRD intensity of the pyrochlore phase and $\mathrm{Pb}\left(\mathrm{Fe}_{2 / 3} \mathrm{~W}_{1 / 3}\right) \mathrm{O}_{3}$. In Fig. 6, the fraction of $\mathrm{Pb}\left(\mathrm{Fe}_{2 / 3} \mathrm{~W}_{1 / 3}\right) \mathrm{O}_{3}$ in precipitated and solid-state reacted samples is compared. As a result, $\mathrm{Pb}\left(\mathrm{Fe}_{2 / 3} \mathrm{~W}_{1 / 3}\right) \mathrm{O}_{3}$ formed in the former process is higher than the latter one at the same temperatures. Therefore, it indicates that the reaction of $\mathrm{Pb}\left(\mathrm{Fe}_{2 / 3} \mathrm{~W}_{1 / 3}\right) \mathrm{O}_{3}$ in precipitated samples proceeded easily. This difference is considered to be related to the size and shape of pyrochlore phase. The facetlike pyrochlore phase appearing in the solid-state reacted samples may increase the diffusion lengths between particles and reduce reaction rate, which results in retardation of $\mathrm{Pb}\left(\mathrm{Fe}_{2 / 3} \mathrm{~W}_{1 / 3}\right) \mathrm{O}_{3}$ formation.

From the XRD results (Fig. 3) of heated samples, $\mathrm{Pb}\left(\mathrm{Fe}_{2 / 3} \mathrm{~W}_{1 / 3}\right) \mathrm{O}_{3}$ did not directly form from constituent compounds but through intermediate compounds. Its reaction mechanism is considered to consist of the formation of pyrochlore phase and its further reaction to form $\mathrm{Pb}\left(\mathrm{Fe}_{2 / 3} \mathrm{~W}_{1 / 3}\right) \mathrm{O}_{3}$. $\mathrm{PbWO}_{4}$ was also a main compound; however, its reaction is considered to have proceeded in the first stage of precipitation. From $700^{\circ}$ to $840^{\circ} \mathrm{C}$, pyrochlore phase coexisted with $\mathrm{Pb}\left(\mathrm{Fe}_{2 / 3} \mathrm{~W}_{1 / 3}\right) \mathrm{O}_{3}$. Further insight into the change in these two phases was obtained by observing the change in lattice constants, as shown in Fig. 7. The lattice constant of pyrochlore phase decreased from $1.0532 \mathrm{~nm}$ to 1. $0442 \mathrm{~nm}$ when heated form $510^{\circ}$ to $840^{\circ} \mathrm{C}$. As for $\mathrm{Pb}\left(\mathrm{Fe}_{2 / 3} \mathrm{~W}_{1 / 3}\right) \mathrm{O}_{3}$, its lattice constant changed slightly from $0.3998 \mathrm{~nm}$ at $700^{\circ} \mathrm{C}$ to $0.3981 \mathrm{~nm}$ at $870^{\circ} \mathrm{C}$. Similar changes for lattice constants of

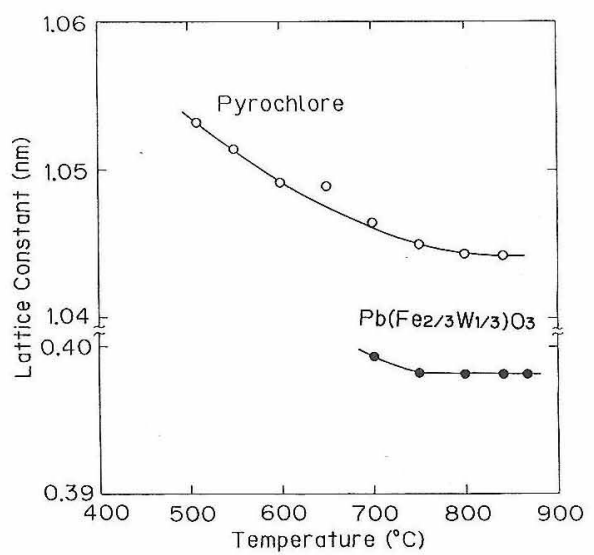

Fig. 7. Lattice constants of $\mathrm{Pb}\left(\mathrm{Fe}_{2 / 3} \mathrm{~W}_{1 / 3}\right) \mathrm{O}_{3}$ and pyrochlore phase versus heating temperatures. 
pyrochlore phases have been found in the $\mathrm{Pb}\left(\mathrm{Zn}_{x} \mathrm{Nb}_{1-x}\right) \mathrm{O}_{3.5-1.5 x}$ system. ${ }^{13)}$ Lattice constants vary easily with the molar ratio of $\mathrm{Zn}$ to $\mathrm{Nb}$. Therefore, the wide variation in lattice constants of pyrochlore phase in this study is indicative of the change in its composition. We have synthesized one pyrochlore phase in the $\mathrm{Pb}-\mathrm{Fe}-\mathrm{W}-\mathrm{O}$ system as $\mathrm{Pb}_{2}(\mathrm{FeW}) \mathrm{O}_{6.5}$ having a lattice constant of $1.0432 \mathrm{~nm} .{ }^{14)}$ The higher lattice constants of the pyrochlore phase in $\mathrm{Pb}\left(\mathrm{Fe}_{2 / 3} \mathrm{~W}_{1 / 3}\right) \mathrm{O}_{3}$ precipitates compared to $\mathrm{Pb}_{2}(\mathrm{FeW}) \mathrm{O}_{6.5}$ can be attributed to the excess amount of lead and iron ions.

In contrast with the solid-state reaction of $3 \mathrm{PbO}_{2} \cdot \mathrm{Fe}_{2} \mathrm{O}_{3} \cdot \mathrm{WO}_{3},{ }^{10 \%, 11}$ the intermediate phases formed in precipitation process were greatly reduced. In addition, the amount of the liquid phase (I ) was greatly decreased. The difference in the liquid phase formation between precipitation and solid-state reaction implies that the reaction process strongly influences its formation. In precipitated powder, segregation of cations is decreased and mixedness of cations will be improved. Precipitates with high homogeneity and reactivity will facilitate the formation process of $\mathrm{Pb}\left(\mathrm{Fe}_{2 / 3} \mathrm{~W}_{1 / 3}\right) \mathrm{O}_{3}$ at low temperatures. After a large amount of pyrochlore phase is formed, the other reaction pathways are suppressed and the formation of intermediate phases including liquid phase is reduced.

As shown in Fig. 3, crystalline forms of iron oxides or hydroxides could not be detected by XRD. To investigate this reason, other precipitation experiments for ferric hydroxides and equal mole of $\mathrm{Pb}$ and $\mathrm{Fe}$ hydroxides were conducted. Ferric hydroxide transformed to $\mathrm{Fe}_{2} \mathrm{O}_{3}$ at $300^{\circ} \mathrm{C}$. $\mathrm{Pb}_{2} \mathrm{Fe}_{2} \mathrm{O}_{5}$ was formed at higher than $600^{\circ} \mathrm{C}$ in $\mathrm{Pb}-\mathrm{Fe}$ hydroxides; however, none of iron oxides or hydroxides appeared in reaction process. Iron ion reacted with lead ion directly without $\mathrm{Fe}_{2} \mathrm{O}_{3}$ formation, which indicates that $\mathrm{Pb}-\mathrm{Fe}$ complex hydroxide may be formed. Thus, a part of $\mathrm{Pb}-\mathrm{Fe}$ complex hydroxide seems to appear in $\mathrm{Pb}\left(\mathrm{Fe}_{2 / 3} \mathrm{~W}_{1 / 3}\right) \mathrm{O}_{3}$ precipitates. Whereas, it is likely to react with $\mathrm{PbWO}_{4}$ to form pyrochlore phase before the formation of $\mathrm{Pb}_{2} \mathrm{Fe}_{2} \mathrm{O}_{5}$.

The two-stage precipitation process in this study was successfully utilized to prepare ferroelectric $\mathrm{Pb}\left(\mathrm{Fe}_{2 / 3} \mathrm{~W}_{1 / 3}\right) \mathrm{O}_{3}$. Additionally, this process led to decrease in the intermediated reactants and effectively simplified the reaction routes of $\mathrm{Pb}\left(\mathrm{Fe}_{2 / 3} \mathrm{~W}_{1 / 3}\right) \mathrm{O}_{3}$. We consider that this process can be effectively applied to synthesize fine ceramic powders of other complex perovskite compounds, especially for the compounds containing lead and tungsten compositions.

\section{Conclusion}

A new two-stage precipitation process was developed to prepare perovskite $\mathrm{Pb}\left(\mathrm{Fe}_{2 / 3} \mathrm{~W}_{1 / 3}\right) \mathrm{O}_{3}$. In the reaction, $\mathrm{PbWO}_{4}$, pyrochlore phase, and $\mathrm{Pb}\left(\mathrm{Fe}_{2 / 3} \mathrm{~W}_{1 / 3}\right) \mathrm{O}_{3}$ formed as three major resultant compounds. Compared with the solid-state reaction, intermediated products in the precipitation process were reduced. During heating, $\mathrm{PbWO}_{4}$ and pyrochlore phase appeared at $300^{\circ}$ and $510^{\circ} \mathrm{C}$, respectively, and $\mathrm{Pb}\left(\mathrm{Fe}_{2 / 3} \mathrm{~W}_{1 / 3}\right) \mathrm{O}_{3}$ increased rapidly above $700^{\circ} \mathrm{C}$. A small amount of liquid phase that increased densification rate was found at $680^{\circ} \mathrm{C}$. Pure $\mathrm{Pb}\left(\mathrm{Fe}_{2 / 3} \mathrm{~W}_{1 / 3}\right) \mathrm{O}_{3}$ formed at $870^{\circ} \mathrm{C}$, and incongruently melted at $930^{\circ} \mathrm{C}$ to form $\mathrm{Pb}_{2} \mathrm{WO}_{5}$ and magnetic $\mathrm{PbFe}_{12} \mathrm{O}_{19}$ which had a facetlike shape. The reaction mechanism for precipitation-derived $\mathrm{Pb}\left(\mathrm{Fe}_{2 / 3} \mathrm{~W}_{1 / 3}\right) \mathrm{O}_{3}$ is considered to include the formation of pyrochlore phase, and its reaction to form $\mathrm{Pb}\left(\mathrm{Fe}_{2 / 3} \mathrm{~W}_{1 / 3}\right) \mathrm{O}_{3}$. Observed simplification in formation process indicates that the homogeneity and reactivity of the starting materials were enhanced in precipitates.

\section{References}

1) P. Duran, L. D. Olmo, C. Moure, G. F. Arroyo and J.R. Jurado, Ferroelectrics, 54, 171-74 (1984).

2) W. K. Lin, M. S. Jou and Y. H. Chang, Ceram. Inter., 14, 223-28 (1988).

3) T. R. N. Kutty and R. Balachandrom, Mater. Res. Bull., 19, 1479-88 (1984).

4) H. M. Quek and M.F. Yan, Ferroelectrics, 74, 95-108 (1987).

5) K. Okuwada, M. Imai and K. Kakuno, Jpn. J. Appl. Phys, , 28, L1271-73 (1989).

6) F. Chaput, J.-P. Boilot, M. Lejeune, R. Papiernik and L.G. Hubert-Pfalzgraf, J. Am. Ceram. Soc., 72, 1335-57 (1989).

7) M. Yonezawa, K. Utsumi and T. Ohno, Proc. 1st Meet. Ferroelectr. Mater. and Appl., Kyoto, 297-301 (1977).

8) M. Yonezawa, Am. Ceram. Soc. Bull., 62, 1375-83 (1983).

9) C. H. Lu, N. Ishizawa, K. Shinozaki, N. Mizutani and M. Kato, J. Mater. Sci. Lett., 7, 1078-79 (1988).

10) M. P. Kassarjian, R. E. Newnham and J. V. Bibbers, Am. Ceram. Soc. Bull。, 64, 1108-11 (1985).

11) C. H. Lu, K. Shinozaki, N. Mizutani and M. Kato, Seramikkusu Ronbunshi, 97, 119-24 (1989).

12) N. Mizutani, C. H. Lu, K. Shinozaki and M. Kato, J. Am. Ceram. Soc., 73, 1214-20 (1990).

13) H. C. Ling, M. F. Yan and W.W. Rhodes, J. Mater. Sci. , 24, 541-48 (1989).

14) C.H. Lu, K. Shinozaki, M. Kato and N. Mizutani, J. Mater. Sci. (in press). 